\title{
PERENCANAAN ARSITEKTUR ENTERPRISE BERBASIS CLOUD COMPUTING MENGGUNAKAN TOGAF (Studi Kasus: PT. XYZ)
}

Mokhamad Wahidin, S.Kom., M.Kom.

E-mail : m.wahidin@dosen.rosma.ac.id

\begin{abstract}
PT. XYZ is a manufacturing company engaged in the production of tires. Good business strategy is necessary for the company to compete with local competitors as well as with other companies in the group XYZ. Business strategy is also needed in order to achieve its goal in providing the best services for customers. Support the implementation of information systems and information technology is needed to support the company's business strategy. Planning of the Enterprise Architecture is necessary for the company to run its business processes. Enterprise architecture is composed of the Business Architecture, Data Architecture, Application Architecture and Technology Architecture. Business processes and organizational activities executed using the data collected, managed, secured and distributed using applications, both custom applications and common applications that run over the technology infrastructure and computer networks. The research report in this thesis discusses about planning the Enterprise Architecture of Manufacturing Information System Architecture Based Cloud Computing using TOGAF, a case study in PT.XYZ. In planning this architecture using the TOGAF-ADM to pass the following stages: Defining planning the Architecture Vision, Planning the Business Architecture, Planning the Information System Architecture, Planning the Technology Architecture, Solutions and Opportunities, Migration Planning, Implementation Management, and Change Management Architecture. The research process is done by looking at the business strategy on the manufacturing process and products distribution from PT. XYZ. The results of this study are planning the enterprise architecture of manufacturing information system at PT. $X Y Z$ to support the implementation of enterprise information systems as a whole, to solve the integration problems of information systems, and improve effectiveness and efficiency in the implementation of information technology infrastructure.
\end{abstract}

Keywords : Business Architecture, Data Architecture, Application Architecture, Architectural Technology, TOGAF-ADM, Cloud Computing. 


\section{PENDAHULUAN}

\section{Latar Belakang}

Pemanfaatan sistem informasi menjadi sebuah keharusan untuk dapat menghadapi persaingan yang semakin ketat saat ini. Sistem informasi memiliki andil dalam menjalankan proses bisnis sebuah perusahaan. Dengan perencanaan sistem informasi yang tepat, akan dapat memenuhi kebutuhan perusahaan terhadap pengelolaan proses-proses di dalamnya, serta dapat memberikan gambaran untuk pengambilan keputusan yang tepat sasaran, efektif, dan efisien.

Implementasi sistem informasi di PT. XYZ masih berjalan secara parsial untuk memenuhi kebutuhan pabrik/ departemen tertentu. Terjadinya hal yang demikian disebabkan kurangnya perencanaan dalam proses pengembangan sistem informasi. Begitu juga dengan penerapan infrastruktur teknologi informasi masih berorientasi pada hasil akhir, ini terjadi akibat kurangnya kesadaran akan perencanaan arsitektur teknologi informasi.

\section{TINJAUAN PUSTAKA}

\section{Sistem Informasi}

Menurut Jogiyanti (2005:11), "Sistem Informasi adalah suatu sistem di dalam suatu organisasi yang mempertemukan kebutuhan pengolahan transaksi harian, mendukung operasi, bersifat manajerial dan kegiatan strategi dari suatu organisasi dan menyediakan pihak luar tertentu dengan laporan-laporan yang diperlukan ".

\section{Enterprise Architecture}

Menurut Bernard (2005), "Enterprise Architecture (disingkat EA) merupakan praktek profesi dan manajemen yang muncul dan ditujukan untuk meningkatkan kinerja perusahaan dengan memungkinkan sebuah perusahaan untuk dapat melihat diri sendiri secara holistis dan melihat integrasi arah strategis perusahaan dengan praktek bisnis, arus informasi, dan sumber daya teknologi".

\section{TOGAF-ADM (Architecture Development Method)}

Menurut Harrison (2009), “Architecture Development Method (ADM) merupakan metodologi logic dari TOGAF yang terdiri dari delapan fase utama untuk pengembangan dan pemeliharaan technical architecture dari organisasi. ADM membentuk sebuah siklus yang iteratif untuk keseluruhan proses, antar fase, dan dalam tiap fase di mana pada tiap-tiap iterasi keputusan baru harus diambil. Keputusan tersebut dimaksudkan untuk menentukan luas cakupan enterprise, level kerincian, target waktu yang ingin dicapai dan asset arsitektural yang akan digali dalam enterprise continuum".

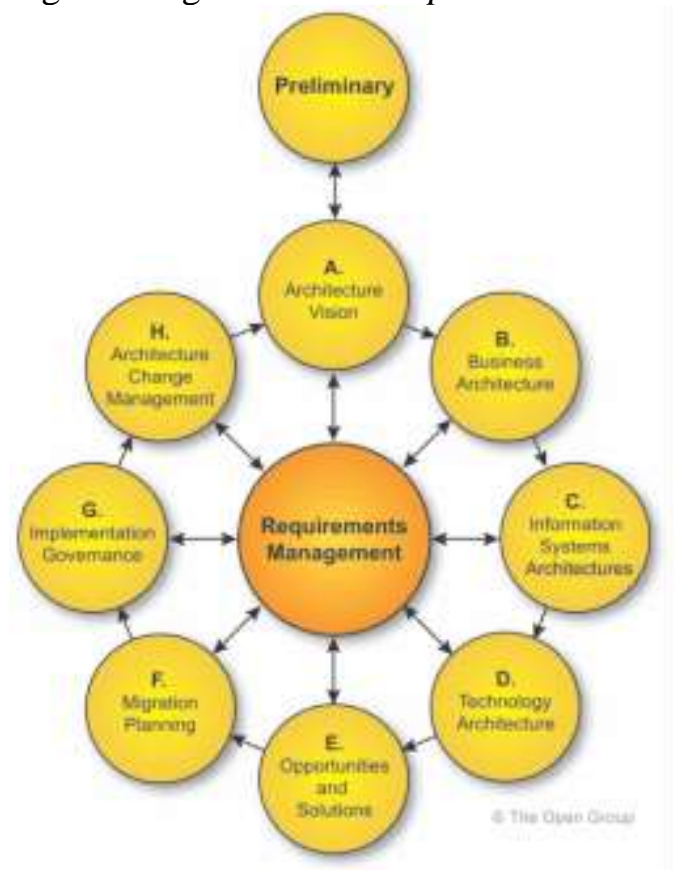

Gambar 1. TOGAF-ADM

\section{Cloud Computing}

Menurut Mell (2011), “Cloud Computing adalah model yang mempermudah ketersediaan, memberikan kenyamanan, serta memungkinkan penggunaan sumber daya komputasi secara bersamaan (jaringan, server, penyimpanan, aplikasi, dan layanan). Dalam model ini suatu layanan dapat dipasang dan dihilangkan dengan mudah".

\section{METODOLOGI PENELITIAN}

\section{Metodologi Penelitian}

Metodologi yang digunakan dalam melakukan perencanaan arsitektur ini menggunakan Framework The Open Group Architecture Technique (TOGAF) dengan metode : ADM ( Achitecture Development Method).

Tahapan metodologi yang digunakan dalam penulisan ini dapat dilihat pada gambar berikut : 


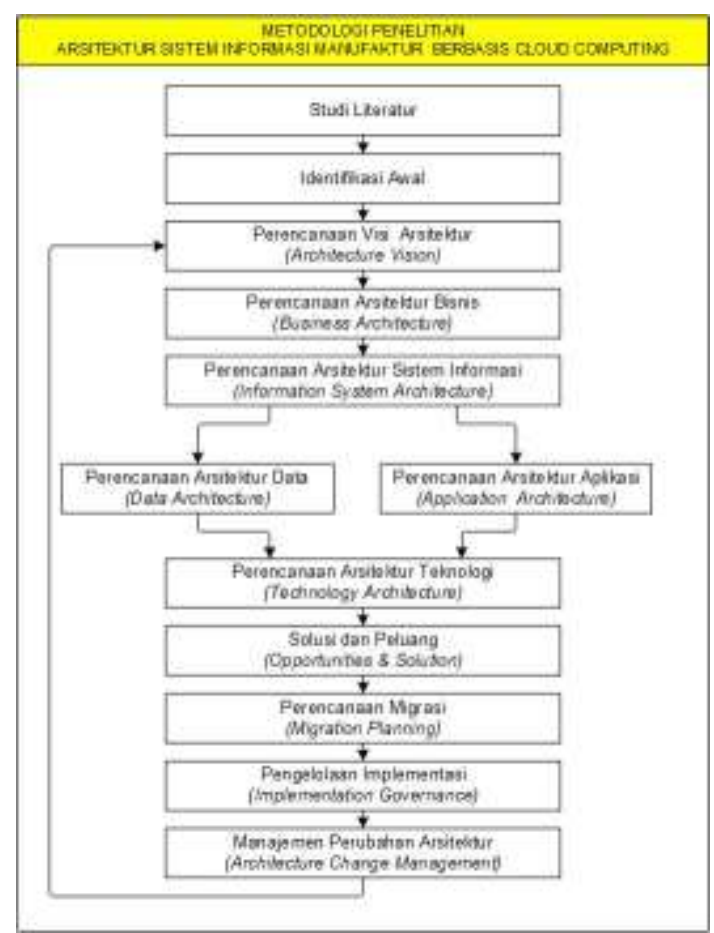

Gambar 2. Tahapan Metodologi Penelitian

\section{HASIL DAN PEMBAHASAN}

\section{Visi Arsitektur Manufaktur}

Tahapan ini bertujuan untuk memperoleh komitmen dan kesamaan pandangan manajemen terkait pentingnya pencapaian tujuan organisasi melalui pengembangan arsitektur enterprise. PT. XYZ memiliki visi sebagai berikut :

1. Perencanaan model arsitektur sistem informasi dan teknologi informasi manufaktur yang sesuai dengan kebutuhan bisnis perusahaan, yang diharapkan mampu menjadikan proses produksi yang efektif dan efisien guna menghadapi persaingan dengan kompetitor maupun antar perusahaan dalam Strategic Business Unit (SBU).

2. Perencanaan proses integrasi arsitektur data maupun arsitektur aplikasi, sehingga aplikasi yang berjalan secara parsial dapat terintegrasi dan sesuai dengan kebutuhan perusahaan untuk meningkatkan daya saing.

3. Perencanaan teknologi informasi dengan konsep arsitektur berbasis Cloud Computing. Dukungan teknologi Cloud Computing ini diharapkan dapat memberi kemudahan dalam pengembangan serta distribusi perangkat lunak di lingkungan PT. XYZ. Dengan penerapan teknologi ini diharapkan dapat meningkatkan efektivitas dan efisiensi dalam arsitektur teknologi.

\section{Perencanaan Arsitektur Bisnis}

Sesuai dengan visi dan misi perusahaan, Perencanaan Arsitektur Bisnis di PT. XYZ didasari dengan prinsip-prinsip berikut ini :

1. Kegiatan bisnis dilakukan dengan tujuan untuk memberikan layanan terbaik bagi pelanggan.

2. Semangat dalam menerapkan budaya perusahaan pada setiap kegiatan bisnis.

3. Pemanfaatan dukungan teknologi informasi yang dapat memenuhi kebutuhan perusahaan dan meningkatkan daya saing.

4. Sesuai dengan tujuan penerapan teknologi berbasis Cloud Computing, maka perlu dilakukan penyesuaian dalam perencanaan arsitektur bisnis. Gap Analysis dari arsitektur bisnis dapat dilihat pada tabel berikut ini :

Tabel 1. Gap Analysis Arsitektur Bisnis

\begin{tabular}{|c|c|c|}
\hline No & $\begin{array}{l}\text { Baseline Business } \\
\text { Arcitecture }\end{array}$ & $\begin{array}{c}\text { Target Business } \\
\text { Arcitecture }\end{array}$ \\
\hline 1 & $\begin{array}{lr}\text { Fungsi } & \text { bisnis } \\
\text { dengan } & \text { terkait } \\
\text { sistem } & \text { pengelolaan } \\
\text { maupun } & \text { informasi } \\
\text { informasi } & \text { teknologi } \\
\text { oleh ICT } & \text { Departakukan } \\
\text { dibawah } & \text { Finance } \\
\text { Division } & \end{array}$ & $\begin{array}{l}\text { Transformasi ICT } \\
\text { Departement menjadi ICT } \\
\text { Division yang melakukan } \\
\text { pelaporan langsung } \\
\text { kepada board (Presiden } \\
\text { Direktur) dan memiliki } \\
\text { kewenangan yang luas } \\
\text { dalam implementasi } \\
\text { sistem informasi/teknologi } \\
\text { informasi berbasis cloud } \\
\text { computing }\end{array}$ \\
\hline 2 & 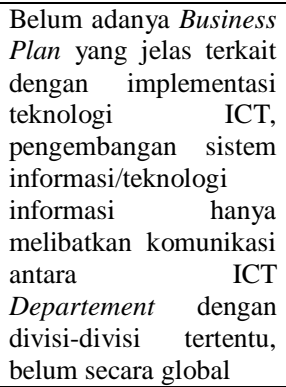 & $\begin{array}{lr}\text { Perubahan } & \text { kebijakan } \\
\text { terkait } & \text { dengan } \\
\text { implementasi teknlogi ICT } \\
\text { yang perlu di aplikasikan } \\
\text { secara global. Komunikasi } \\
\text { dilakukan } \\
\text { dengan } \\
\text { organization, langsung } \\
\text { memasukkan dengan } \\
\text { implementasi ICT pada } \\
\text { Business Goal and } \\
\text { Objective perusahaan }\end{array}$ \\
\hline 3 & $\begin{array}{l}\text { Belum adanya prosedur } \\
\text { kerja atau factory policy } \\
\text { yang terkait dengan } \\
\text { kegiatan ICT }\end{array}$ & $\begin{array}{l}\text { Penyesuaian prosedur } \\
\text { kerja dan factory policy } \\
\text { yang didalamnya terdapat } \\
\text { kebijakan terkait dengan } \\
\text { implementasi teknologi } \\
\text { ICT }\end{array}$ \\
\hline
\end{tabular}

\section{Perencanaan Arsitektur Sistem Informasi}

Tahapan ini dilakukan perencanaan arsitektur sistem informasi yang meliputi perencanaan arsitektur data dan perencanaan arsitektur aplikasi pada PT. XYZ. 
Tabel 2. Gap Analysis Arsitektur Data

\begin{tabular}{|c|c|c|}
\hline 0 & $\begin{array}{c}\text { Baseline Data } \\
\text { Arcitecture }\end{array}$ & $\begin{array}{l}\text { Target Data } \\
\text { Arcitecture }\end{array}$ \\
\hline 1 & $\begin{array}{l}\text { Pengelolaan } \\
\text { data belum } \\
\text { terpusat, } \\
\text { masing-masing } \\
\text { sistem aplikasi } \\
\text { memiliki } \\
\text { database } \\
\text { tersendiri }\end{array}$ & $\begin{array}{lr}\text { Pengolahan } & \text { data } \\
\text { terpusat, dan } \\
\text { terintegrasi } \\
\text { sama lain. Yatu } \\
\text { menjamin } \\
\text { ketersediaannya } \\
\text { Availability) }\end{array}$ \\
\hline 2 & $\begin{array}{l}\text { Tingkat } \\
\text { keamanan data } \\
\text { masih belum } \\
\text { terjamin, } \\
\text { terdapat } \\
\text { beberapa } \\
\text { database yang } \\
\text { masih } \\
\text { menggunakan } \\
\text { tingkat } \\
\text { keamanan } \\
\text { secara default } \\
\end{array}$ & $\begin{array}{lr}\text { Perbaikan } & \text { tingkat } \\
\text { keamanan } & \text { data } \\
\text { dengan melakukan } \\
\text { standarisasi } \\
\text { keamanan data dan } \\
\text { melakukan evaluasi } \\
\text { otentikasi } \\
\text { database } \\
\text { berkala. }\end{array}$ \\
\hline 3 & $\begin{array}{l}\text { Adanya } \\
\text { duplikasi data } \\
\text { terutama untuk } \\
\text { sistem informasi } \\
\text { yang berkaitan } \\
\text { dengan } \\
\text { produksi, } \\
\text { dimana data } \\
\text { dikembangkan } \\
\text { untuk dua pabrik } \\
\text { yang berbeda }\end{array}$ & $\begin{array}{l}\text { Meskipun terdapat } \\
\text { dua pabrik yang } \\
\text { berbeda, pengolahan } \\
\text { data direncanakan } \\
\text { untuk dilakukan } \\
\text { unifikasi, sehingga } \\
\text { tidak terdapat } \\
\text { duplikasi database. }\end{array}$ \\
\hline 4 & $\begin{array}{l}\text { Terdapat } \\
\text { beberapa data } \\
\text { yang dibuat dan } \\
\text { diedit secara } \\
\text { manual, } \\
\text { misalkan } \\
\text { menggunakan } \\
\text { aplikasi } \\
\text { Microsoft } \\
\text { Excel }\end{array}$ & $\begin{array}{l}\text { Pengolahan data } \\
\text { terpusat } \\
\text { memanfaatkan } \\
\text { database yang } \\
\text { disesuaikan dengan } \\
\text { kebutuhan. }\end{array}$ \\
\hline 5 & $\begin{array}{l}\text { Belum tingginya } \\
\text { kesadaran untuk } \\
\text { melakukan } \\
\text { backup data. } \\
\text { Sehingga ketika } \\
\text { terjadi data } \\
\text { permasalahan } \\
\text { pada mengakibatkan } \\
\text { menganggunya } \\
\text { tergeses kerja. }\end{array}$ & $\begin{array}{lr}\text { Perencanaan } & \text { backup } \\
\text { data secara berkala } \\
\text { dan otomoatis, serta } \\
\text { dilakukan } & \\
\text { pengetesan } & \text { data } \\
\text { backup } & \text { secara } \\
\text { berkala } & \text { untuk } \\
\text { menjamin } & \\
\text { keberhasilan } & \\
\text { pemulihan } & \text { data } \\
\text { ketika } & \text { terjadi } \\
\text { masalah } & \\
\end{array}$ \\
\hline 6 & $\begin{array}{l}\text { Kurangnya } \\
\text { interkoneksi } \\
\text { antara data yang } \\
\text { dibutuhkan }\end{array}$ & $\begin{array}{l}\text { Perencanaan data } \\
\text { dengan } \\
\text { memanfaatkan } \\
\text { teknologi cloud }\end{array}$ \\
\hline
\end{tabular}

\begin{tabular}{|c|l|l|}
\hline No & \multicolumn{1}{|c|}{$\begin{array}{c}\text { Baseline Data } \\
\text { Arcitecture }\end{array}$} & \multicolumn{1}{|c|}{$\begin{array}{c}\text { Target Data } \\
\text { Arcitecture }\end{array}$} \\
\hline \multirow{6}{*}{$\begin{array}{l}\text { secara internal } \\
\text { dengan data } \\
\text { yang dibutuhkan } \\
\text { oleh pihak luar } \\
\text { dapat dengan mudah } \\
\text { (supplier, } \\
\text { distributor, dll) }\end{array}$} & $\begin{array}{l}\text { diakses melalui } \\
\text { infrastruktur } \\
\text { eksternal }\end{array}$ \\
\end{tabular}

Tabel 3. Gap Analysis Arsitektur Aplikasi

\begin{tabular}{|c|c|c|}
\hline No & $\begin{array}{c}\text { Baseline } \\
\text { Application } \\
\text { Arcitecture }\end{array}$ & $\begin{array}{l}\text { Target Application } \\
\text { Arcitecture }\end{array}$ \\
\hline 1 & $\begin{array}{l}\text { Tingkat } \\
\text { keamanan } \\
\text { aplikasi masih } \\
\text { belum terjamin, } \\
\text { dan belum adanya } \\
\text { intergrasi } \\
\text { aplikasi. }\end{array}$ & $\begin{array}{l}\text { Perbaikan tingkat } \\
\text { keamanan aplikasi } \\
\text { melalui integrasi } \\
\text { dengan teknologi } \\
\text { Active Dirrectory, } \\
\text { namun tetap } \\
\text { memperhatikan } \\
\text { kemudahan } \\
\text { pengelolaannya } \\
\text { melalui pengaturan } \\
\text { Singe Sign On ( satu } \\
\text { otentikasi untuk } \\
\text { beberapa aplikasi) }\end{array}$ \\
\hline 2 & $\begin{array}{l}\text { Adanya duplikasi } \\
\text { aplikasi terutama } \\
\text { untuk sistem } \\
\text { informasi yang } \\
\text { berkaitan dengan } \\
\text { produksi, dimana } \\
\text { aplikasi } \\
\text { dikembangkan } \\
\text { untuk dua pabrik } \\
\text { yang berbeda } \\
\end{array}$ & $\begin{array}{l}\text { Meskipun terdapat } \\
\text { dua pabrik yang } \\
\text { berbeda, pengolahan } \\
\text { aplikasi } \\
\text { direncanakan untuk } \\
\text { dilakukan unifikasi, } \\
\text { sehingga ridak } \\
\text { terdapat duplikasi } \\
\text { aplikasi. }\end{array}$ \\
\hline 3 & $\begin{array}{l}\text { Kurangnya } \\
\text { interkoneksi } \\
\text { antara aplikasi } \\
\text { yang dibutuhkan } \\
\text { secara internal } \\
\text { dengan aplikasi } \\
\text { yang dibutuhkan } \\
\text { oleh pihak luar } \\
\text { (supplier, } \\
\text { distributor, dll) }\end{array}$ & $\begin{array}{l}\text { Perencanaan aplikasi } \\
\text { dengan } \\
\text { memanfaatkan } \\
\text { teknologi cloud } \\
\text { computing sehinga } \\
\text { dapat dengan mudah } \\
\text { diakses melalui } \\
\text { infrastruktur } \\
\text { eksternal }\end{array}$ \\
\hline
\end{tabular}

\section{Perencanaan Arsitektur Teknologi}

Setelah dilakukan perencanaan arsitektur sistem informasi, selanjutnya dilakukan perencanaan arsitektur teknologi pada PT. XYZ. Perencanaan arsitektur ini dibuat dengan memperhatikan output dari tahapan-tahapan sebelumnya. 
Tabel 4. Gap Analysis Arsitektur Teknologi

\begin{tabular}{|c|c|c|}
\hline No & $\begin{array}{c}\text { Baseline } \\
\text { Technology } \\
\text { Arcitecture }\end{array}$ & $\begin{array}{c}\text { Target Technology } \\
\text { Arcitecture }\end{array}$ \\
\hline 1 & $\begin{array}{l}\text { Adanya variasi } \\
\text { vendor pada } \\
\text { perangkat } \\
\text { jaringan yang } \\
\text { terkadang } \\
\text { menghambat } \\
\text { implementasi } \\
\text { teknologi } \\
\text { jaringan } \\
\text { (operasional } \\
\text { maupun } \\
\text { monitoring) } \\
\end{array}$ & $\begin{array}{l}\text { Standarisasi penggunaan } \\
\text { vendor perangkat } \\
\text { jaringan menggunakan } \\
\text { perangkat } \text { Cisco }^{\circledR} \\
\text { Sehingga memudahkan } \\
\text { dalam proses operasional } \\
\text { dan monitoringnya }\end{array}$ \\
\hline 2 & $\begin{array}{l}\text { Penggunaan } \\
\text { media } \\
\text { komunikasi } \\
\text { telapon analog } \\
\text { menggunakan } \\
P A B X\end{array}$ & $\begin{array}{l}\text { Pemanfaatan teknologi } \\
\text { IP Phone / VOIP untuk } \\
\text { berkomunikasi secara } \\
\text { digital, dan } \\
\text { memungkinkan dilakuan } \\
\text { Unified Communication } \\
\text { yaitu komunikasi suara } \\
\text { (voice) maupun gambar } \\
\text { bergerak (Video) melalui } \\
\text { jaringan data. }\end{array}$ \\
\hline 3 & $\begin{array}{l}\text { Masih } \\
\text { terdapatnya } \\
\text { beberapa server } \\
\text { fisik yang } \\
\text { menangani } \\
\text { aplikasi, dan } \\
\text { tidak sebanding } \\
\text { dengan sumber } \\
\text { daya yang } \\
\text { digunakan } \\
\end{array}$ & $\begin{array}{l}\text { Migrasi server fisik ke } \\
\text { server virtual guna } \\
\text { mendukung penerapan } \\
\text { teknologi Cloud baik } \\
\text { secara Private Cloud, } \\
\text { maupun Public Cloud. }\end{array}$ \\
\hline 4 & $\begin{array}{l}\text { Interkoneksi } \\
\text { Internet dengan } \\
\text { sewa kecepatan } \\
\text { data kurang dari } \\
\text { 10Mbps, dan } \\
\text { belum adanya } \\
\text { backup link } \\
\text { untuk internet } \\
\end{array}$ & $\begin{array}{l}\text { Interkoneksi internet } \\
\text { dengan kecepatan diatas } \\
\text { 50Mbps untuk } \\
\text { mendukung penerapan } \\
\text { teknologi cloud } \\
\text { computing, dan } \\
\text { penyediaan backup link } \\
\text { untuk koneksi internet }\end{array}$ \\
\hline 5 & $\begin{array}{l}\text { Interkoneksi } \\
\text { WAN dengan } \\
\text { kecepatan data } \\
\text { hanya 10Mbps } \\
\text { terdiri dari } \\
\text { 5Mbps link A, } \\
\text { dan 5Mbps link } \\
\text { B (Backup) } \\
\end{array}$ & $\begin{array}{l}\text { Peningkatan kecepatan } \\
\text { interkoneksi WAN } \\
\text { dengan kecepatan diatas } \\
\text { 50Mbps }\end{array}$ \\
\hline 6 & $\begin{array}{l}\text { Belum } \\
\text { tersedianya } \\
\text { Rencana } \\
\text { Pemulihan } \\
\text { Bencana } \\
\text { (Disaster } \\
\text { Recovery Plant) } \\
\end{array}$ & $\begin{array}{l}\text { Penambahan } \\
\text { infrastruktur untuk } \\
\text { menjamin } \\
\text { keberlangsungan bisnis } \\
\text { (Business Continuity) }\end{array}$ \\
\hline
\end{tabular}

\section{Solusi dan peluang}

Tahapan ini artifak (View Point) dari perencanaan arsitektur enterprise dapat digunakan untuk memberikan gambaran penerapan solusi bisnis di PT. XYZ.

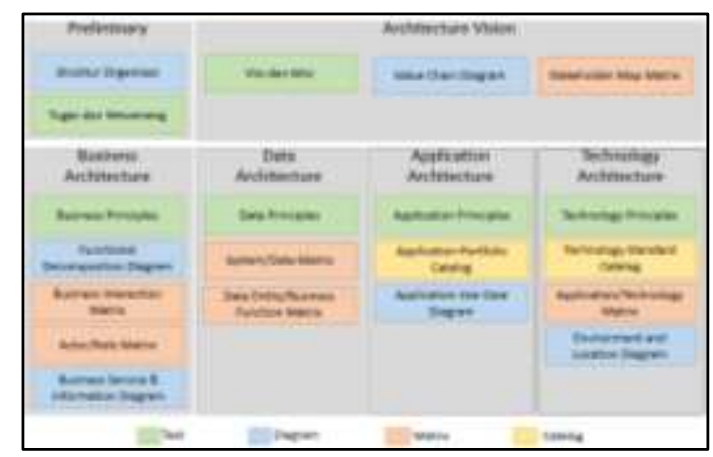

Gambar 3. Enterprise Architecture View Point

Faktor-faktor yang dilakukan penilaian beserta keputusan yang harus diambil dapat dilihat pada tabel berikut :

Tabel 5. Faktor penilaian dan keputusan yang harus diambil

\begin{tabular}{|c|c|c|c|}
\hline No & Faktor & Penjelasan & Deduksi \\
\hline 1 & $\begin{array}{l}\text { Perubahan } \\
\text { dalam } \\
\text { implemen } \\
\text { tasi } \\
\text { aplikasi }\end{array}$ & $\begin{array}{l}\text { Implementasi } \\
\text { aplikasi } \\
\text { menggunakan } \\
\text { cloud } \\
\text { dibanding } \\
\text { dengan } \\
\text { aplikasi saat } \\
\text { ini (tidak } \\
\text { menggunakan } \\
\text { cloud) }\end{array}$ & 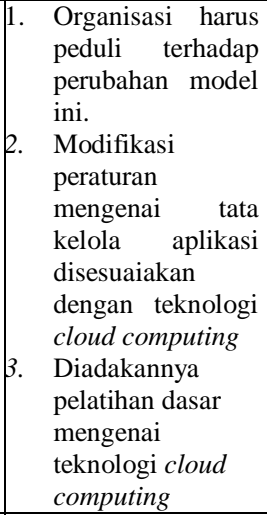 \\
\hline 2 & $\begin{array}{l}\text { Integrasi } \\
\text { Aplikasi }\end{array}$ & $\begin{array}{l}\text { Integrasi } \\
\text { antara aplikasi } \\
\text { on-premises } \\
\text { dengan } \\
\text { aplikasi yang } \\
\text { ada di cloud }\end{array}$ & 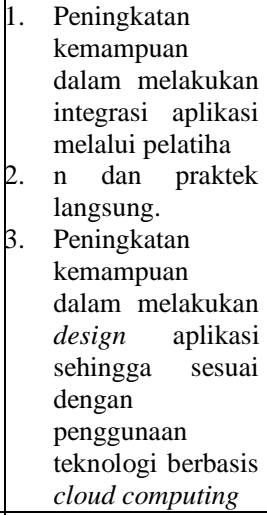 \\
\hline 3 & $\begin{array}{l}\text { Fungsi } \\
\text { Bisnis dan } \\
\text { Data }\end{array}$ & $\begin{array}{l}\text { Fungsi bisnis } \\
\text { dan data } \\
\text { secara } \\
\text { tradisional } \\
\text { belum berada } \\
\text { pada cloud }\end{array}$ & $\begin{array}{l}\text { 1. Pembuatan } \\
\text { mekanisme dalam } \\
\text { penentuan fungsi } \\
\text { bisnis apa saja } \\
\text { yang dapat di } \\
\text { letakkan dalam } \\
\text { cloud baik itu } \\
\text { secara } \\
\text { public/private/hyb } \\
\text { rid. } \\
\text { 2. Pembuatan } \\
\text { mekanisme dalam } \\
\text { penentuan data }\end{array}$ \\
\hline
\end{tabular}




\begin{tabular}{|c|c|c|c|}
\hline No & Faktor & Penjelasan & Deduksi \\
\hline & & & $\begin{array}{l}\text { apa saja yang } \\
\text { dapat di letakkan } \\
\text { dalam } \text { cloud }\end{array}$ \\
\hline 4 & $\begin{array}{l}\text { Availabilit } \\
y, \\
\text { Scalabilit } \\
y, \\
\text { Elasticity }\end{array}$ & $\begin{array}{l}\text { Aplikasi } \\
\text { terjamin } \\
\text { ketersediaann } \\
\text { ya, } \\
\text { skalabilitas } \\
\text { dan } \\
\text { elastisitasnya }\end{array}$ & $\begin{array}{ll}\text { 1. } & \text { Penyediaan } \\
\text { sarana backup dan } \\
\text { recovery sesuai } \\
\text { dengan yang telah } \\
\text { dijanjikan divisi } \\
\text { ICT dalam KPI } \\
\text { 2. } \\
\text { Perancangan } \\
\text { teknologi yang } \\
\text { mampu } \\
\text { mencukupi } \\
\text { kebutuhan saat in } \\
\text { dan juga saat yang } \\
\text { akan datang }\end{array}$ \\
\hline
\end{tabular}

\section{Perencanaan Migrasi}

Dalam tahap ini dilakukan perencanaan perpindahan / migrasi dari arsitektur saat ini (baseline) menjadi arsitektur tujuan (Target). Secara umum, rencana penjadwalan migrasi arsitektur enterprise dapat dilihat pada tabel berikut ini :

Tabel 6. Gobal Schedule

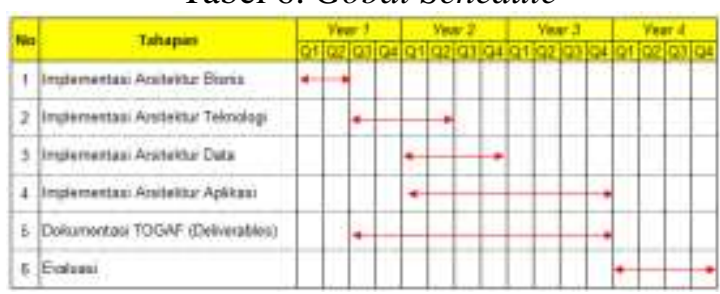

\section{Pengelolaan Implementasi}

Fokus pada tahapan ini adalah untuk memastikan implementasi arsitektur aplikasi sesuai dengan target arsitektur enterprise dengan pemanfaatan teknologi berbasis cloud computing. Pada penelitian ini penulis memberikan rekomendasi penggunaan kerangka kerja ITIL v3 (Information Technology Infrastructure Library)

Siklus layanan dalam ITIL terdri dari

beberapa tahapan sebagai berikut :

1. Service Strategy, dalam siklus ini ditentukan strategi apa yang akan digunakan dalam implementasi sistem.

2. Service Design, memberikan panduan dalam mendesain layanan ICT agar dapat terimplementasi.

3. Service Transition, Untuk mengetahui kebutuhan dalam merealisasikan implementasi teknologi ICT

4. Service Operation, Kegiatan operasional dalam tata kelola layanan ICT

\section{Manajemen Perubahan Arsitektur}

Tahapan ini memastikan bahwa implementasi arsitektur enterprise dapat memberikan nilai bisnis yang maksimal. Berikut ini adalah beberapa hal yang perlu untuk dilakukan terkait dengan manajemen perubahan arsitektur :

1. Perbaikan terus menerus terhadap kemampuan arsitektur enterprise dalam melakukan transformasi proses bisnis perusahaan.

2. Perbaikan kinerja pada bagian operasional yang memungkinkan untuk dilakukan pengambilan keputusan yang efisien sehingga dapat memberikan kepuasan kepada pelanggan (internal maupun eksternal).

3. Kebutuhan untuk melakukan perubahan cara costumer, supplier, dan distributor dalam berinterkasi dengan arsitektur enterprise di PT. XYZ.

4. Melakukan risk assessment secara berkala pada arsitektur enterprise di PT. XYZ untuk meminimalisir terjadinya kesalahan. Dan kegagalan sistem.

\section{KESIMPULAN DAN SARAN}

\section{Kesimpulan}

Berdasarkan hasil penelitian dengan melalui tahapan-tahapan perencanaan yang telah dilakukan, dapat diambil beberapa kesimpulan terkait dengan perencanaan arsitektur enterprise di PT. XYZ sebagai berikut :

1. Metodologi TOGAF merupakan metode yang sesuai bagi PT. XYZ dalam melakukan perencanaan arsitektur enterprise berbasis teknologi cloud computing. Hasil perencanaan setiap tahapan dalam metodologi TOGAF sesuai dengan visi dan misi perusahaan dalam menyumbang masyarakat dengan mutu tertinggi, dan guna meningkatkan daya saing dengan kompetitor.

2. Perencanaan arsitektur bisnis di PT. XYZ menghasilkan kejelasan kaitan antara proses bisnis perusahaan dengan pelaku di dalamnya sehingga dapat memberikan gambaran bagi perusahaan untuk menjalankan layanan bisnis yang efektif dan efisien.

3. Perencanaan arsitektur sistem informasi yang didalamnya terdapat perencanaan arsitektur data dan arsitektur aplikasi, mampu memberikan pemetaan kebutuhan bisnis terhadap data dan aplikasi di PT. XYZ 
guna menghadapi persaingan dengan kompetitor maupun antar perusahaan dalam Strategic Business Unit (SBU).

4. Perencanaan arsitektur sistem informasi dapat membantu proses integrasi arsitektur data maupun arsitektur aplikasi, sehingga aplikasi yang berjalan secara parsial dapat terintegrasi dan sesuai dengan kebutuhan perusahaan untuk meningkatkan daya saing.

5. Perencanaan teknologi informasi dengan konsep arsitektur berbasis cloud computing dapat memberi kemudahan dalam pengembangan serta distribusi layanan ICT di lingkungan PT. XYZ.

\section{Saran}

Berikut adalah saran dari penulis agar hasil penelitian ini dapat memberikan manfaat yang positif bagi PT. XYZ dalam menjalankan proses bisnis perusahaan manufaktur berbasis teknologi cloud computing, dan guna memberikan layanan terbaik bagi masayarakat, serta meningkatkan daya saing :

1. Perlunya kesadaran bersama pada setiap lini organisasi di PT. XYZ untuk dapat memahami dan mendukung arsitektur enterprise yang akan diterapkan di perusahaan. Penerapan arsitektur enterprise ini tidak dapat berjalan hanya dengan dukungan dari manajemen tertinggi di perusahaan, tetapi perlu juga mendapat dukungan dari tingkatan lainnya (karyawan).

2. Perlunya komitmen dan ketegasan dalam penerapan arsitektur enterprise di PT. XYZ, hal ini diperlukan mengingat seringnya terjadi pergantian manajemen tingkat atas, dimana pada tingkatan ini masih dipegang oleh ekspatriat asing.

3. Perlunya dokumentasi yang jelas terkait dengan perencanaan arsitetur enterprise dan sosialisasi terhadap seluruh lini organiasasi di PT. XYZ. Dengan dokumentasi yang baik diharapkan dapat memberikan informasi yang tepat bagi penenentuan pengambilan keputusan oleh manajemen tingkat atas. Dengan dokumentasi yang baik diharapkan juga dapat mengatasi masalah yang timbul akibat seringnya terjadi pergantian manajemen tingkat atas.

4. Perlunya dilakukan review secara berkala terhadap rencana implementasi arsitektur enterprise agar dapat dilakukan evaluasi dalam setiap tahapan yang dilakukan.

\section{DAFTAR PUSTAKA}

Afriandi,Arif, Perancangan Implementasi dan Analisis Kinerja Virtualisasi Server, Jurnal Teknologi Akprind, 2012

Al-Bahra, Ladjamudin, Analisis dan Desain Sistem Informasi, Graha Ilmu, Yogyakarta, 2005

Amin, Sistem Informasi Manufaktur Vaksin Berstandar GMP (Good Manufacturing Practices) Menggunakan Framework TOGAF, STMIK LIKMI, 2011

Bernard,Scott A, An Introduction to Enterprise Architecture $2^{\text {nd }}$ Edition, Author House, USA, 2005

Budiyanto,Alex, Pengantar Cloud Computing, CloudIndonesia.ORG, Jakarta, 2012

Chandrasekaran,K, Essential Of Cloud Computing, CRC Press, USA, 2015

Fowler,Martin, UML Destilled Edisi 3 Panduan Singkat Bahasa Objek Standar, Andi Offset, 2005

Hadiana,Ana, Perencanaan \& Pengembangan Sistem Informasi Terpadu, Penerbit Megatama, Bandung, 2016

Harrison, Rachel, TOGAFTM Version 9 Foundation Study Guide - Preparation for the TOGAF 9 Part I Examination, Van haren Publishing, USA, 2009

Herucakra,AG, Ari Fajar, Ridha Hanafi, Sistem Informasi manufaktur vaksin berstandar GMP (Food Manufacturing Practices) Menggunakan Framework TOGAF, Universitas Telkom, 2012

Jogiyanto,HM., MA.,Akt.,Ph.D., Analisis dan Desain Sistem Informasi Pendekatan Terstruktur dan Aplikasi Bisnis, Penerbit Andi,Yogyakarta, 2006

Kurniawan,Boby, Enterprise Architecture Planning Sistem Informasi Pada Perguruan Tinggi Swasta Dengan Zachman Framework, Majalah Ilmiah Unikom Vol 9 No1, Bandung, 2011

Laudon,Kenneth C dan Jane P Laudon, Management Information Systems Managing The Digital Firm Fourteenth Edition, Pearson, USA, 2015

Marlina,Ekawati, Budi Nugroho, Arsitektur Pengembangan Sistem Pengelolalan Jurnal Ilmiah Indonesia Menggunakan Framework TOGAF, LIPI, 2014

Mell,Petter and Timothy Grance, The NIST Definition of Cloud Computing, National Institute of Standards and Technology, 2011 
Morville,Peter dan Louis Rosenfield, Information Architecture for the World Wide Web, O’Reilly Media, USA, 2006

Mulyanto,Agus, Sistem Informasi Konsep dan Aplikasi, Pustaka Pelajar, Yogyakarta, 2009

Porter,Michael, Competitive Advantage: Creating and Sustaining Superior Performance. Simon and Schuster, New York, 1985

Setiawan,Erwin, Pemilihan EA Framework, Prosiding SNATI, Yogyakarta, 2009

Solichin, Achmad, Hasibuan Zainal A, Pemodelan Arsitektur Teknologi Informasi Berbasis Cloud Computing Untuk Institusi Perguruan Tinggi di Indonesia, Semantik,Semarang, 2012

Tahriludin,Udin, Perancangan Enterprise Arsitektur Menggunakan Kerangka Kerja TOGAF-ADM, UKI, 2014

Valdez,Alicia, Practical Application of Enterprise Architecture, Study Case of SME Metalmechanic in Mexico, European Scientific Journal, 2014

Ward,J., and Peppard, J. Strategic Planning for Information Systems. 3th Edition. John Wiley \& Sons, Ltd., USA. 2003

Yunis,Roni, Krisdanto Surendro, dan Erwin Panjaitan, Pengembangan Model Arsitektur Enterprise untuk Perguruan tinggi, JUTI Volume 8 hal 9-18, 2010 